\title{
DIASPORA PRAWOSŁAWNA WE WROCŁAWIU. PRAKTYCZNE PROBLEMY SOCJALIZACJI I EDUKACJI RELIGIJNEJ (PERSPEKTYWA RODZICA)
}

\author{
Mojemu Mistrzowi - \\ ks. prof. ChAT dr. hab. Bogusławowi Milerskiemu
}

\begin{abstract}
Streszczenie: Bycie członkiem mniejszości wiąże się z utrudnieniami w funkcjonowaniu w różnych obszarach życia. Utrudnienia te dotyczą także edukacji oraz życia religijnego. Są one skutkiem zarówno czynników natury obiektywnej, takich jak przepisy prawa, organizacja nauczania religii czy tradycja religijna, a również subiektywnej, czyli np. braku religijnej gotowości rodziców lub problemów z wytłumaczeniem dziecku jego „odmienności” od rówieśników wyznających religię większościową. Tego typu trudności doświadczają także członkowie diaspory prawosławnej we Wrocławiu - szczególnie rodzice, ale też dzieci po osiągnięciu pewnego wieku i bardziej już świadome swej odrębności religijnej. Artykuł przedstawia praktyczne problemy oraz szanse związane z socjalizacją religijną oraz nauczaniem religii widziane oczami prawosławnego rodzica.
\end{abstract}

Słowa kluczowe: socjalizacja religijna; nauczanie religii; wyznanie mniejszościowe; diaspora prawosławna.

Bycie członkiem mniejszości niesie ze sobą utrudnienia w funkcjonowaniu w różnych obszarach życia. Czy w obszarze socjalizacji religijnej oraz szkolnego nauczania religii można dostrzegać jedynie problemy, których doświadczają członkowie diaspory prawosławnej we Wrocławiu? Czy „inność” prawosławnych dzieci to tylko kłopot - dla nich i rodziców - czy może także szansa dla wyznawców religii mniejszościowej? Pytania te stały się inspiracją do powstania niniejszego tekstu.

Lilla Busłowska, pisząc o prawosławnej myśli pedagogicznej, wskazuje na trzy obszary, w których odbywa się edukacja religijna: „Bycia chrześcijaninem dziecko uczy się w swoim domu, otoczeniu. Dlatego w obszarze edukacji religijnej konieczna jest praca w trzech obszarach: domu rodzinnego, parafii, edukacji religijnej w szkole" (2012, s. 64) ${ }^{1}$. Niniejszy artykuł dotyczy dwóch kwestii: socjalizacji

1 Podobnie określa środowiska wychowania religijnego pedagog religii Bogusław Milerski. Zob.: rozdział Edukacja religijna jako zadanie rodziny, Kościoła i szkoły (1998a, s. 129-155). 
religijnej, odbywającej się głównie w środowisku rodzinnym, szkolnego nauczania religii w parafii. Każda z części tekstu kończy się podsumowaniem, w którym zastosowano technikę SWOT ${ }^{2}$.

Encyklopedia Obyczaje, języki, ludy świata diasporę definiuje jako „rozproszenia jednej narodowości wśród innej, także rozproszenie wyznawców jednej religii wśród innowierców; [...] diasporą nazywa się też społeczność rozproszonych wierzących lub terytorium, na którym żyją" (2007, s. 172). Chociaż niektórzy socjologowie odmawiają miana diaspory mniejszości religijnej, żyjącej wśród społeczności wyznania większościowego, w niniejszym artykule diaspora będzie rozumiana jako terytorium, na którym wyznawcy prawosławia są mniejszością żyjącą w rozproszeniu, oraz jako sama ta społeczność.

Przyjmując, że „edukacja religijna jest praktyką prowadzenie człowieka w kierunku religii, wychodzącą z założenia, że dzięki niej człowiek może pozyskać określoną tożsamość, samozrozumienie i orientację w otoczeniu oraz w sposobach działania, co w konsekwencji umożliwi mu lepszy indywidualny rozwój w bardziej sprawiedliwym świecie" (Milerski 1998a, s. 144), należy stwierdzić, że odbywa się ona w pierwszej kolejności w domu rodzinnym jako element socjalizacji pierwotnej oraz w szkole i innych instytucjach (np. Kościele), będących czynnikami socjalizacji wtórnej (Giddens 2005, s. 50-51). Socjalizacja jest procesem poznawania przez dziecko języka, wzorów zachowań i wartości, przekonań oraz norm kulturowych społeczeństwa, w którym przyszło na świat i w którym żyje, w tym także norm i wartości wynikających z nauczania Kościoła i wzorców zachowań religijnych ${ }^{3}$. Efektem prawidłowej socjalizacji jest skuteczne funkcjonowanie człowieka w świecie społecznym, w tym także w świecie wierzeń, wartości i religii. To, jak dzieci należące do mniejszościowego Kościoła prawosławnego będą funkcjonowały wobec katolickiej większości, zależy z jednej strony od jakości socjalizacji religijnej, z drugiej zaś od nauczania religii, które w 1990 roku zostało ponownie włączone do programu szkół publicznych.

Powyższe kwestie są niezmiernie istotne, ponieważ wyznawcy prawosławia pod wieloma względami odróżniają się w społeczeństwie katolickim ${ }^{4}$ Beata Łaciak (1998, s. 84-88), przedstawiając świat społeczny dzieci, podkreśla znaczenie wspólnoty doświadczeń i świadomości, które odnoszone są do znaczących partnerów interakcji społecznych. Tymi partnerami są dwie grupy rówieśnicze - koledzy z podwórka i z klasy. Wspólnej świadomości nie sprzyja sytuacja rozproszenia, nawet

2 Analiza SWOT służy do oceny mocnych i słabych stron oraz szans i zagrożeń. Stosowana jest do oceny rozwiązań biznesowych czy projektów, może być także użyta do oceny instytucji i jej elementów.

3 Choć obecnie w naukach społecznych przyjmuje się, że socjalizacja trwa przez całe życie, na potrzeby niniejszego artykułu pojęcie socjalizacji odnoszone będzie do okresu dzieciństwa.

4 Protestanci nie odróżniają się na co dzień od rzymskokatolickiej większości tym, że w innym czasie obchodzą święta. 
przy wpajaniu wspólnych norm religijno-moralnych i kulturowych. Dzieci żyjące $\mathrm{w}$ diasporze mają doświadczenia i przeżycia, które łączą je z innymi prawosławnymi dziećmi, z którymi mogą „tworzyć poczucie podobnego postrzegania, rozumienia i przeżywania" (Łaciak 1998, s. 88), ale ze względu na przestrzenne rozproszenie brakuje im wspólnej świadomości. Z dziećmi katolickimi nie podzielają natomiast wielu religijno-wspólnotowych doświadczeń. Dla prawosławnych dzieci (a także ich rodziców) to sytuacja trudna, ponieważ kwestia ,inności” ma ogromne znaczenie i potrafi stać się z jednej strony powodem ostracyzmu wobec kogoś „innego”, z drugiej zaś strony - jest czasem powodem cierpienia dziecka, podlegającego społecznej ekskluzji.

\section{Socjalizacja religijna}

Książkę Chrześcijańskie wychowanie. Rozważania i porady dla prawosławnej rodziny rozpoczyna stwierdzeniem: „Kwestia wychowania dzieci to główne zadanie, jakie stawia przed rodzicami życie [...] Jak zatem wychować dziecko na dobrego chrześcijanina? [...] Jej [książki - A. S.] główną ideą jest wskazanie [...] rodzicom takiego kierunku wychowywania dzieci, który przez wieki pozostaje niezmienny, choć nie zawsze jest wygodny do realizowania i zgodny z duchem czasu - kierunku, w którego centrum stoi Chrystus i Ewangelia" (2014, s. 11). Powyższe wskazania odnoszą się do wszystkich chrześcijańskich rodziców, mających takie samo zadanie dotyczące religijnego wychowania dzieci. Prawosławni rodzice, żyjący w diasporze, podejmują to wyzwanie, stykając się z różnymi problemami.

\section{Kalendarz juliański i różnice w datach świąt}

Cerkiew prawosławna - inaczej niż Kościół rzymskokatolicki i Kościoły protestanckie - posługuje się kalendarzem juliańskim ${ }^{5}$, w którym daty następują $\mathrm{z}$ trzynastodniowym przesunięciem $\mathrm{w}$ stosunku do kalendarza gregoriańskiego i zarazem państwowego. Utrudnia to życie prawosławnym rodzicom i wymaga od nich kreatywności w tłumaczeniu dzieciom rachuby czasu, która nie dla wszystkich dorosłych jest jasna. Jednym z głównych problemów jest obchodzenie dnia św. Mikołaja. W Polsce „Mikołaj przynosi grzecznym dzieciom prezenty” 6 grudnia. W kalendarzu juliańskim dzień św. Mikołaj przypada natomiast 19 grudnia. Wiadomo, że dzieci wymieniają się informacjami o tym, co które z nich dostało. Jeżeli któreś dziecko nie otrzyma prezentu 6 grudnia, to dla koleżanek i kolegów

5 Niektóre parafie prawosławne w Polsce posługują się tzw. nowym stylem, czyli kalendarzem gregoriańskim.

6 Dzieciom luterańskim prezenty przynosi Dzieciątko w czasie Bożego Narodzenia. Jednak ze względów kulturowych niektóre otrzymują też prezenty „mikołajkowe”, a wrocławska parafia Ewangelicko-Augsburska organizuje spotkanie z Mikołajem dla dzieci ze szkółki niedzielnej. 
będzie to sygnał, że na niego nie zasłużyło, bo „Mikołaj wszystko widzi i wie, kto był grzeczny". Zatem ten wyjątkowy dzień jest sporym wyzwaniem dla rodziców $z$ diaspory prawosławnej. $Z$ informacji zebranych przez autorkę niniejszego artykułu wśród rodziców z wrocławskiej parafii Kościoła prawosławnego wynika, że ich dzieci otrzymują prezenty i 6, i 19 grudnia ${ }^{7}$. Poza tym, zwłaszcza w rodzinach, w których część członków jest wyznania rzymskokatolickiego (przypadek małżeństw mieszanych), podobna sytuacja ma miejsce z prezentami z okazji Bożego Narodzenia (Rożdjestwa Christowa), którego wigilia według kalendarza juliańskiego przypada 6 stycznia. Oznacza to dwukrotnie więcej wydatków na prezenty i cały miesiąc (od 6 grudnia do 6 stycznia), w którym dzieci je otrzymują.

Juliański kalendarz i Rożdjestwo to także logistyczne problemy związane z wypełnieniem dzieciom dni wolnych, w których obchodzone są katolickie święta, oraz zwalnianiem ich z przedszkola czy szkoły w terminie 7-9 stycznia, gdy - tuż po świątecznej przerwie w szkole - prawosławni obchodzą Boże Narodzenie. To także choinka pojawiająca się 13 dni później i znów podkreślana „inność”, nie zawsze rozumiana przez same prawosławne dzieci, a jeszcze rzadziej - przez ich koleżanki i kolegów należących do Kościoła większościowego.

\section{Język cerkiewnosłowiański}

Kolejnym problemem jest język cerkiewnosłowiański ${ }^{8}$, którym posługuje się większość prawosławnych parafii ${ }^{9}$. W kwestii tej Włodzimierz Misijuk, wikariusz prawosławnej Parafii Zaśnięcia NMP w Białymstoku, pisze: „Zwróćmy uwagę na to, jak w czasie nabożeństw zachowują się nasze dzieci. Jeżeli w ogóle przychodzą [...] do cerkwi, bywają zwykle dziwnie ospałe, znudzone czy zniecierpliwione [...] albo też szukają sobie jakiegoś zajęcia. [...] Czy zdajemy sobie sprawę, że w dużym stopniu ich zachowanie jest konsekwencją nierozumienia, co się wokół nich dzieje?" (2007, s. 13). Trudno oprzeć się wrażeniu, że utrzymywany siłą tradycji cerkiewny język liturgiczny staje się zaprzeczeniem misji prowadzonej wśród Słowian przez świętych Cyryla i Metodego, którzy przełożyli Pismo Święte i księgi liturgiczne na język słowiański właśnie po to, aby nabożeństwa były zrozumiałe dla mieszkańców krajów, w których prowadzili swoją działalność. Jeżeli święci bracia uważali

$7 \mathrm{Z}$ metodologicznego punktu widzenia nie są to badania, ponieważ informacje uzyskano u wybranych rodziców na zasadzie kontaktów towarzyskich autorki i w nieporównywalnych oraz niestandaryzowanych warunkach. Uzyskane informacje pozwalają jednak odpowiedzieć na pytanie, jak niektórzy prawosławni rodzice rozwiązują omawiany problem.

8 Język cerkiewnosłowiański (staro-cerkiewno-słowiański, starosłowiański, starocerkiewny): „najstarszy liturgiczny język słowiański, zapisany w połowie IX w. w celach misyjnych przez braci Cyryla [...] i Metodego. [...] od IX do XVIII w. był wspólnym językiem liturgicznym i kulturowym Słowian z kręgu kultury bizantyjskiej i obrządków wschodnich” (Kaczorowski 2007, s. 729-730).

9 We Wrocławiu w jednej prawosławnej parafii nabożeństwa odprawiane są w języku polskim. 
rozumienie tekstów Biblii i modlitw za niezbędne dla chrystianizacji Słowian, to dlaczego współcześni wyznawcy prawosławia uparcie wprowadzają swoje dzieci w religię, ucząc je modlić się niezrozumiałymi słowami: „Otcze nasz, Iże jesi na niebiesiech. Da swiatitsia Imia Twoje, da pryidiet Carstwije Twoje, da budiet wola Twoja..." (Modlitwy dla najmłodszych, 2015, s. 40)? W. Misijuk zwraca uwagę na jeszcze jeden aspekt dotyczący posługiwania się w Cerkwi starożytnym językiem oraz starym kalendarzem: przyczynia się to do wyraźnego oddzielenia życia religijnego i Cerkwi od reszty zsekularyzowanego życia, w którym obowiązuje inny kalendarz i mówi się w innym języku (2007, s. 23). Autor zwraca też uwagę na istotne niebezpieczeństwo, że „nieznajomość języka liturgicznego może, szczególnie u dzieci, wywoływać niepokojące przeświadczenie, że słowa modlitwy działają jak magiczne zaklęcia - wystarczy je tylko wypowiedzieć" (2007, s. 31). Tu zaznacza się zadanie rodziców, aby nauczyć dzieci podstawowych modlitw, umiejętności czytania w języku cerkiewnosłowiańskim i jego podstaw, ale także, aby zadbać o prawidłowe rozumienie powodów odmienności języka (i kalendarza) świeckiego i religijnego.

Kalendarz juliański i język cerkiewnosłowiański to jedne z najbardziej charakterystycznych elementów zewnętrznych wyróżniających Kościół prawosławny. Zachowanie ich odrębności jest sposobem na przekazywanie tradycji i zachowanie prawosławnej tożsamości ${ }^{10}$, gdyż „tożsamość wyznaniowa jest pewnym rodzajem duchowego zadomowienia, jest konkretną kościelną tożsamością. Chrześcijanami stajemy się bowiem i jesteśmy zawsze w konkretnym Kościele czy wspólnocie kościelnej" (Jaskóła 2010, s. 26).

$\mathrm{W}$ tym kontekście warto zaakcentować jeszcze dwa zagadnienia: pierwszym jest stałość i przywiązanie do tradycji, drugim - rola języka jako wyznacznika zbiorowej tożsamości. Znaczenie tradycji i stałości dla wzmocnienia prawosławnej tożsamości dobrze charakteryzuje wypowiedź Dumitru Vancy: „Kult jest autoportretem Kościoła [...] chrześcijanie czują, że należą do grupy, wykorzystującej pewien zestaw «liturgicznych instrumentów», które każde pokolenie nabywa [...] od poprzedniego pokolenia. [...] Prawosławny Wschód zachował liturgiczną ciągłość, związek między pokoleniami: ta sama liturgia, ta sama aranżacja przestrzeni i przedmiotów liturgicznych; te same pieśni, które słyszałeś w dzieciństwie, wszystko to przynosi spokój wewnętrzny i eschatologiczne szczęście. Bez względu

10 Kwestie tożsamości religijnej i wyznaniowej poruszane są w kontekście ekumenizmu (Jaskóła 2010), bezpieczeństwa religijnego w społeczeństwie wielokulturowym (Harbatski 2015) czy dialogu międzyreligijnego (Rydz i in. 2017). Odnośnie do tożsamości konfesyjnej wyznawców prawosławia istotne jest podejście Roberta Speamanna, który „,analizując tożsamościową funkcję grup religijnych, wyróżnia trzy obszary znaczenia tożsamości religijnej [...] ostatni opisuje tożsamość konkretnej wspólnoty wyznaniowej z jej tradycją, pismami, przekonaniami i więziami istniejącymi pomiędzy wyznawcami” (Wieradzka-Pilarczyk 2015, s. 91-92). 
na to, czy są praktykującymi chrześcijanami czy nie, ich Kościół jest kościołem ich rodziców i przodków" (Vanca, brw.).

W drugiej kwestii znaczącą opinię wyraził Tomasz Wicherkiewicz, pisząc o ginących językach i etniczności oraz etnokonfesyjności: „,istotną rolę odgrywa [...] język jako [...] symboliczny wyznacznik zbiorowej tożsamości etnicznej [...] grupa ludzi uważa się za jeden naród/grupę etniczną [...] właśnie dlatego, że mówi tą samą odmianą językową, podczas gdy otaczające ją inne grupy mówią odmianami od niej różnymi” $(2014)^{11}$. Uzasadnione jest mówienie o takiej właśnie roli cerkiewnosłowiańskiego jako języka odróżniającego prawosławnych chrześcijan od przedstawicieli innych chrześcijańskich denominacji. Czasami sami wyznawcy prawosławia bronią swojego języka liturgicznego, powołując się na jego tradycyjny charakter oraz rolę w przekazywaniu cerkiewnej tożsamości. Prawosławny niemiecki pianista, Nikolaj L. Strauss, wiąże cerkiewnosłowiański z prawosławną tożsamością i tradycją następująco: „na Cerkiew w Polsce wielki wpływ ma Kościół katolicki. Zaczniecie wprowadzać język polski, potem zmienicie szaty liturgiczne, jeszcze bardziej skrócicie czas nabożeństw i krok po kroku staniecie się bliźniakiem Kościoła katolickiego" (O naszym prawosławiu, 2010, s. 197).

\section{Brak Pierwszej Komunii}

Kolejnym elementem wyróżniającym prawosławne dzieci na tle rzymskokatolickiej większości jest brak Pierwszej Komunii. Prawosławni trzecioklasiści znajdują się w podobnej sytuacji jak ich protestanccy rówieśnicy: nie obchodzą tej uroczystości z większością kolegów i koleżanek z klasy. Prawosławne dzieci przyjmują bowiem Święte Dary już od chrztu, natomiast osiągnięcie wieku szkolnego uważane jest w Kościele prawosławnym za odpowiedni moment na pierwszą spowiedź. Wielu prawosławnych rodziców wykorzystuje to wydarzenie jako powód do zorganizowania dziecku uroczystości rodzinnej przypominającej tę pierwszokomunijną, żeby zrekompensować mu brak uczestnictwa w uroczystościach, w których biorą udział jego rówieśnicy należący do Kościoła rzymskokatolickiego. Ale pierwsza spowiedź może być traktowana jako rytuał przejścia ${ }^{12}$ - „do tego czasu dziecko przystępowało do Eucharystii bez jakichkolwiek wymagań" (Chrześcijańskie wychowanie..., 2014, s. 84), teraz nadszedł moment „samodzielnej wiary i osobistej odpowiedzialności przed Bogiem" (Chrześcijańskie wychowanie..., 2014, s. 34), od którego nie można już bez pokajania i postu przyjmować Świętych Darów; jako moment, kiedy kończy się duchowe dzieciństwo. Sakralnym rytuałom przejścia zwykle towarzyszą obrzędy i uroczystości świeckie. Taki może być sens tych rodzinnych obchodów.

11 O cerkiewnosłowiańskim autor pisze, że jest jednym z ,języków klasycznych/martwych obecnych w pewnych sferach zawodowych [...] czy używanych w liturgiach" (Wicherkiewicz 2014, s. 35).

12 „Zbiorowe ceremonie, często o charakterze sakralnym, symbolizujące koniec jednej fazy życia i początek następnej” (Sztompka 2004, s. 416). 
Nie zmienia to faktu, że klasa trzecia to moment, w którym prawosławne dzieci mogą poczuć się ,inne” lub zostać za takie uznane przez rzymskokatolickich rówieśników. Zwłaszcza jeśli do klasy szkolnej uczęszczają dzieci należące do jednej parafii, razem uczestniczące w przygotowaniach do Pierwszej Komunii i razem ją przyjmujące. W takiej sytuacji znów pojawia się problem prezentów, o których dzieci opowiadają sobie w szkole. Od mądrości rodziców i umiejętnego przygotowania dzieci zależy, jak sobie z tym poradzą.

Patrząc na powyższe kwestie, zgodnie z techniką porządkowania informacji SWOT, zauważamy, że wśród mocnych stron języka cerkiewnosłowiańskiego są jego uniwersalność i międzynarodowość na obszarach świata słowiańskiego, co pozwala wiernym uczestniczyć na podobnym poziomie w nabożeństwach w różnych krajach tego obszaru. Język jest też sposobem zachowania i przekazywania prawosławnej tradycji, w tym modlitw. Znajomość języka cerkiewnosłowiańskiego to także pewnego rodzaju szansa i ułatwienie w późniejszym czasie nauki innych języków słowiańskich. Zagrożeniami jednak mogą stać się wspomniana „magiczność" języka liturgicznego oraz odchodzenie od prawosławia ze względu na niezrozumiałość treści nabożeństw.

Stosowanie w Kościele prawosławnym kalendarza juliańskiego wiąże się ze wspomnianymi już problemami organizacyjnymi. Niektóre święta państwowe czy katolickie wypadają podczas prawosławnych postów (np. Sylwester i Nowy Rok podczas Postu Filipowego). Za mocną stronę można uznać zachowywanie tradycji, zaś szans upatrywać w częściowym przynajmniej uniknięciu komercjalizacji świąt (ostatnie 13 dni przed prawosławnym Bożym Narodzeniem i tydzień/dwa przed Paschą ${ }^{13}$ są spokojniejsze, a sklepy nie atakują promocjami). $Z$ zagrożeń warto przypomnieć „odrealnienie” i oderwanie życia religijnego od życia codziennego.

Największą zaletą braku Pierwszej Komunii jest mniejsze skomercjalizowanie pierwszej spowiedzi świętej, szansą staje się więc duchowe, indywidualne jej przeżycie. Ale to zindywidualizowanie stanowi zarazem zagrożenie, ponieważ wiąże się z odsunięciem dziecka od jego grupy szkolnej i utrwaleniem poczucia „inności”. Argumentem przemawiającym na korzyść zindywidualizowanego podejścia do pierwszego przyjęcia Eucharystii może być pojawiający się w Kościele rzymskokatolickim zwyczaj komunii indywidualnych ${ }^{14}$.

13 Jeżeli prawosławna Pascha i katolicka Wielkanoc nie pokrywają się w czasie.

14 Przykładowe regulacje dotyczące tej kwestii w Kościele katolickim: https://www.gosc.pl/ doc/1749717.Do-Pierwszej-Komunii-rodzinnie-albo-grupowo, https://kosciol.wiara.pl/doc /1730842.I-Komunia-inaczej. Na stronie Instytutu Statystyki Kościoła Katolickiego (http:// iskk.pl/) brak danych dotyczących częstotliwości stosowania takiego rozwiązania. 


\section{Szkolne nauczanie religii}

Oprócz domu rodzinnego ważne miejsce w procesie edukacji religijnej przypada szkolnej nauce religii. „Wasze dzieci powinny być wykształcone, uczone. Ale ważne, żeby ich kształcenie i wychowanie nie ograniczało się tylko do mądrości świeckiej [...]. Nadzwyczaj ważne jest, żeby równocześnie z nią poznawały wyższą prawdę, uczyły się prawa Bożego i przykazań miłości, przyuczały się do ciągłej pobożności, żeby zgłębiając nauki zawsze pamiętały o Bogu i jego przykazaniach oraz postępowały drogą Chrystusa. Wtedy i tylko wtedy nie pobłądzą na drodze ludzkiej mądrości, tylko wtedy będą wyżej ponad wszystko cenić mądrość chrześcijańską i poznanie Boga. Tak powinniście uczyć swoje dzieci" (św. Łukasz [Wojno-Jasieniecki], brw.). I chociaż św. Łukasz pełnił posługę na terenach, gdzie prawosławie było religią dominującą ${ }^{15}$, to jego wezwanie pozostaje aktualne a może jeszcze ważniejsze - tam, gdzie wyznawcy prawosławia żyją w diasporze. Odpowiadając na nie, rodzice muszą podjąć decyzję co do uczestnictwa ich dzieci w przedszkolnym i szkolnym nauczaniu religii, w czasie którego będą one poznawać treści wiary, naukę Kościoła i sposoby rozwiązywania problemów zgodnie z nauką Bożą. Ta kwestia jest prostsza dla rodziców należących do Kościoła, którego religia nauczana jest w ramach zajęć szkolnych - większościowego lub mniejszościowego, którego wyznawców na danym terenie jest odpowiednio wielu (np. wyznawcy prawosławia w województwach wschodniej Polski, luteranie w południowo-wschodniej części Śląska ${ }^{16}$ ). Inaczej sprawa wygląda na terenach, gdzie wyznawcy Kościołów mniejszościowych są rozproszeni, a ich dzieci w danym przedziale wiekowym jest tak mało, że w lekcjach religii mogą uczestniczyć tylko w międzyszkolnych punktach katechetycznych przy parafiach.

Gdy po roku 1990 nauka religii powróciła do szkół publicznych, możliwość organizowania szkolnych lekcji religii otrzymały różne Kościoły, w tym Polski Autokefaliczny Kościół Prawosławny. Możliwość nauczania religii dają Kościołowi prawosławnemu: Ustawa $\mathrm{z}$ dnia 17 maja 1989 roku o gwarancjach wolności sumienia i wyznania, Ustawa z dnia 4 lipca 1991 roku o stosunku Państwa do Polskiego Autokefalicznego Kościoła Prawosławnego oraz Ustawa z dnia 7 września 1991 roku o systemie oświaty. Rozporządzenie Ministra Edukacji Narodowej z dnia 7 czerwca 2017 roku, zmieniające Rozporządzenie w sprawie warunków i sposobu organizowania nauki religii w publicznych przedszkolach i szkołach, aktualizuje natomiast przepisy z roku 1992 i zawiera praktyczne wskazania związane z prowadzeniem nauki religii w szkołach.

15 Św. Łukasz (Wojno-Jasieniecki) był arcybiskupem symferopolskim i krymskim.

16 B. Milerski twierdzi odnośnie do organizacji lekcji religii ewangelickiej w Polsce: „nasze lekcje odbywają się często w budynkach parafialnych. Poza Śląskiem Cieszyńskim, gdzie nauczanie religii ewangelickiej w szkole jest na ogół normą, nie udaje się zebrać dość licznych grup" (Pezda, brw.). 
Z powyższych przepisów wynika, że zajęcia z religii prawosławnej może w publicznej szkole lub przedszkolu prowadzić osoba, która otrzymała od lokalnego biskupa misję kanoniczną na nauczanie religii. Zgodnie z Porozumieniem pomiędzy Polską Radą Ekumeniczną oraz Ministrem Edukacji Narodowej z dnia 24 kwietnia 2013 roku w sprawie kwalifikacji wymaganych od nauczycieli religii Kościołów zrzeszonych w PRE, osoba nauczająca religii - poza przygotowaniem pedagogicznym - musi mieć w przypadku nauczania w liceach i technikach ukończone studia wyższe, zaś w przypadku przedszkoli, szkół podstawowych i zasadniczych szkół zawodowych - studia pierwszego stopnia o kierunku teologia lub pedagogika w specjalności przygotowującej do nauczania religii lub na innym kierunku, uzupełnione o studia podyplomowe przygotowujące do nauczanie religii lub kurs teologiczny. L. Busłowska wysoko ocenia kwalifikacje zawodowe tak przygotowanych prawosławnych katechetów i dodaje, że „wszyscy nauczyciele religii prawosławnej objęci są doradztwem metodycznym, co [...] niewątpliwie wpływa na podniesienie efektywności kształcenia w zakresie edukacji religijnej" (2012, s. 238).

Zgodnie z informacjami umieszczonymi na stronie internetowej MEN, w roku szkolnym 2015/2016 w Polsce w nauce religii wyznania prawosławnego uczestniczyło około 15 tys. uczniów, a zajęcia, odbywające się w szkole (w klasach lub grupach międzyklasowych) lub w grupach międzyszkolnych, prowadzone były przez 301 nauczycieli (Konferencja Wizytatorów i Doradców Metodycznych Nauczania Religii Prawosławnej z udziałem wiceministra edukacji, 2017). Nauczanie religii prawosławnej, poza tym co dotychczas zostało opisane, stanowi również wyzwanie dla rodziców.

\section{Organizacja zajęć religii mniejszościowej}

W miastach i miejscowościach, gdzie wyznawcy prawosławia żyją w diasporze, lekcje religii organizowane są $\mathrm{w}$ punktach parafialnych i łączą w grupy lekcyjne dzieci na różnym poziomie nauczania, np. przedszkolaki z dziećmi z klas I-III, uczniów podstawówek z gimnazjalistami. Nawet wtedy grupy zajęciowe są zaledwie kilkuosobowe. W niektórych parafiach lekcje odbywają się w niedziele, bezpośrednio po Świętej Liturgii, w innych - w tygodniu w godzinach popołudniowych, gdy dzieci wrócą ze szkoły, a rodzice mogą je przywieźć na zajęcia. We wrocławskiej katedrze parafii prawosławnej lekcje dla przedszkolaków i uczniów klas pierwszych rozpoczynają się o 17.40. Jest to godzina tak późna, że możliwości percepcyjne dzieci są już mocno ograniczone.

\section{Program nauczania i ocena $\mathrm{z}$ religii}

Szkolna edukacja religijna podlega ocenianiu, a program nauczania religii prawosławnej wśród metod kontroli osiągnięć ucznia wskazuje jego aktywność pozalekcyjną - udział w życiu Kościoła, parafii (Podstawa programowa i program nauczania religii prawosławnej, 2012). Aktywny udział w życiu Kościoła i parafii 
zasługuje na ocenę celującą, chętny - na bardzo dobrą, zaś po prostu włączanie się w życie parafii - na dobrą. Uczeń, który stara się uczestniczyć w życiu parafii, powinien otrzymać ocenę dostateczną. W zaleceniach programu znalazły się np. uczestnictwo w parafialnych zawodach sportowych czy kole ikonograficznym. Ale działania takie nie są zwykle prowadzone w warunkach diaspory. W dodatku podstawa programowa i program posługują się sformułowaniami typu: „Zadaniem nauczyciela religii jest wprowadzenie ucznia, we współpracy z rodzicami i parafią” czy „Nauczanie religii w szkołach powinno być prowadzone w korelacji z działaniami podejmowanymi w parafii" (Podstawa programowa..., s. 10, 40). Są to więc programy przygotowane do szkolnego nauczania religii prawosławnej na terenach Polski wschodniej; katecheci pracujący w diasporze muszą je przystosowywać do warunków, z jakimi mają do czynienia na co dzień. Tak skonstruowane programy nauczania oznaczają dla rodziców większe zaangażowanie czasowe i przywożenie dzieci do parafii często oddalonej od ich miejsca zamieszkania (dwie wrocławskie cerkwie skupiają wyznawców prawosławia także z okolicznych miejscowości), aby mogły nie tylko uczęszczać na lekcje religii, lecz także angażować się w życie parafialne (choć de facto toczy się ono zwykle w niedzielę i przy okazji świąt).

\section{Prawosławne dzieci w placówkach oświatowych podczas lekcji religii większościowej}

Zgodnie z Informacją dotycząca organizowania zajęć z religii i etyki w publicznych przedszkolach i szkołach w roku szkolnym 2016/2017, dostępną na stronie internetowej MEN, w gestii dyrektora leży umieszczenie tych lekcji w planie zajęć szkolnych lub ramowym rozkładzie dnia oddziału przedszkolnego. Sprawa jest prostsza w szkołach, gdzie lekcje trwają w określonych godzinach, a do dyspozycji są świetlice i biblioteki, w których dzieci nieuczęszczające na lekcje religii mogą spędzić czas pod opieką nauczycieli. Idealnym rozwiązaniem jest zorganizowanie zajęć $z$ religii w pierwszych lub ostatnich godzinach lekcyjnych. Sytuacja jest trudniejsza w przedszkolach, do których dzieci przyprowadzane są do określonej godziny, odbierane natomiast o różnych porach. Placówki te nie dysponują świetlicami, dzieci należące do mniejszości wyznaniowych są więc zwykle wyprowadzane do innej grupy na czas trwania zajęć z religii większościowej. Biorąc pod uwagę, że w wielu przedszkolach wyprowadzenie do innej grupy (zwykle młodszej) jest stosowane jako kara, mamy sytuację, w której dziecko „karane” jest za swoją religijną odmienność. W dodatku sytuacja dotyczy dzieci w wieku od 3 do 6-7 lat, którym trudno pojąć przyczyny takiego postępowania.

Rozpatrując szkolną edukację religijną z punktu widzenia analizy SWOT, należy zwrócić uwagę na program nauczania, który angażuje dzieci i rodziców w życie parafii - to jego mocna strona. Jednak w diasporze realne zaangażowanie bywa niemal niemożliwe do zrealizowania i to jest już słabą stroną obowiązującego programu. Szans można upatrywać w zwiększaniu odpowiedzialności rodziców za edukację i życie religijne dzieci. Zagrożeniem, związanym z trzymaniem się 
wytycznych dotyczących systemu oceniania, jest stawianie uczniom niższych ocen w przypadku braku zaangażowania w działalność parafialną, co może zaowocować rezygnacją z lekcji religii, ale też ignorowanie przez katechetów tych wytycznych, gdyż w małej, diasporalnej społeczności więzy są szczególnie mocne ${ }^{17}$. Jak charakteryzuje subiektywną więź społeczną Piotr Sztompka: „ludzie podobnego wyznania czują się sobie bliżsi niż wyznawcy odmiennych religii (np. katolicy, protestanci, wyznawcy islamu)" (2006, s. 185). Oznacza to, że prawosławni katecheci mogą pomijać wskazania programu i stawiać swym prawosławnym uczniom wyższe oceny, aby w ten sposób pomagać im osiągać wyższą średnią.

Organizacja lekcji religii w małych grupach to szansa na indywidualne podejście do uczniów. Za zagrożenia należy natomiast uznać łączenie w grupy dzieci i młodzieży w różnym wieku, co może powodować niedostosowanie treści nauczania do poziomu percepcyjnego części odbiorców.

Co do zapewniania opieki prawosławnym dzieciom podczas lekcji religii większościowej, w stosowanych praktykach mocną stroną jest jedynie niedostarczanie im treści niezgodnych z wyznawaną wiarą (np. wiadomości o papieżu, uznawanym przez Kościół prawosławny tylko za biskupa Rzymu). Szansą jest zorganizowanie zajęć religii większościowej na początku lub pod koniec pobytu dziecka w placówce edukacyjnej. Zagrożeniem zaś - uznawane za karę - wyprowadzanie do innej grupy, a także pozbawienie prawosławnych dzieci możliwości poznawania elementów kultury wyznania większościowego, co mogłoby być czynnikiem poszerzającym horyzonty poznawcze ${ }^{18}$ i ułatwiającym im funkcjonowanie w środowisku wyznającym inną religię.

Ryszard Kapuściński w wykładzie Mój Inny wymienia trzy najważniejsze cechy Innego: rasa, narodowość i religia ,jako instytucja i jako siła społeczna” (2006, s. 46) i dodaje: „Szukam, co jest wspólnego w tych cechach [...]. Otóż jest w nich wszystkich zawarty wielki ładunek emocjonalny" (Kapuściński 2006, s. 46). Reportażysta pisał o Innych spotykanych w odległych krajach, ale w dzisiejszym zglobalizowanym świecie ludzie - także dzieci - stykają się z Innymi również „u siebie”. Wielu mieszkających we Wrocławiu wyznawców prawosławia jest dla Polaków - katolików Innymi, od których odróżniają ich często dwie wymienione przez Kapuścińskiego cechy: narodowość ${ }^{19}$ (a także inny język ojczysty) i religia. Różnice w tak emocjonal-

17 Na silne więzi łączące wspólnoty (w tym grupy wyznaniowe) oraz gotowość udzielania wzajemnej pomocy między ich członkami w sytuacji niepewności i zagrożenia zwraca uwagę Wojciech Sitek, porównując zagrożenie, przed jakim stanęli wrocławianie w 1997 roku (Sitek 1997) do sytuacji opisanych w pamiętnikach Łemków przesiedlonych w ramach Akcji „Wisła” (Sitek [red.]. 1996).

18 Zob.: programy edukacyjne realizowane w Dzielnicy Wzajemnego Szacunku Czterech Wyznań we Wrocławiu (Sanecka 2017).

19 Wrocławscy prawosławni to często Łemkowie lub Ukraińcy. 
nie newralgicznych obszarach wiążą się z zagrożeniem wykluczenia dziecka, które różni się od grupy większościowej, oraz wynikającymi z tego różnymi trudnościami dla prawosławnych rodziców, są jednak też szansą na budowanie i wzmacnianie własnej - osobistej i społecznej - tożsamości prawosławnych wrocławian. Na tę szansę zwraca uwagę Bogusław Milerski, pisząc o innej religijnej mniejszości żyjącej w Polsce w diasporze: „Bycie ewangelikiem [...] jest dla zewnętrznego otoczenia [...] poznawczą nieoczywistością ${ }^{20}$. Owa nieoczywistość zostaje odzwierciedlona na poziomie świadomości samych protestantów. O ile więc katolicyzm przestaje dostarczać jednostce identyfikacji [...], o tyle protestantyzm w Polsce stanowi istotny punkt odniesienia na drodze budowania własnej tożsamości. Zależność ta wypływa [...] nie tyle z faktu bycia ewangelikiem, ile życia w diasporze jako mniejszości wyznaniowej" (Milerski, http://www.kosciolzbawiciela.pl/pl/blog/12). Ta diasporalna szansa jest otwarta także dla zamieszkujących Wrocław wyznawców prawosławia. Jej wykorzystanie zależeć będzie między innymi od stopnia dojrzałości (także religijnej) i samoświadomości prawosławnych rodziców, jak również od ich gotowości wychowywania i socjalizowania dzieci w tradycji religii mniejszościowej oraz dostrzegania nie tylko problemów z nią związanych, lecz także wynikających z niej szans. Jak konstatuje L. Busłowska: „Ważnym elementem w obszarze aktywności Kościoła w najbliższej przyszłości zdaje się «edukacja dorosłych» w zakresie wdrażania prawosławnej myśli pedagogicznej w systemie wychowania młodego człowieka. [...] Wzmocnienie skierowanych do rodziców różnorodnych form pomocy, która mogłaby dostarczyć motywacji i inspiracji tym, którym zależy na wychowaniu religijnym swoich dzieci" (2012, s. 240). Te motywacje i inspiracje są szczególnie pożądane przez prawosławnych rodziców żyjących w diasporze.

\section{Bibliografia}

Busłowska L. (2012). Prawosławna myśl pedagogiczna. Aksjomat wiary w szkolnym systemie nauczania religii Polskiego Autokefalicznego Kościoła Prawosławnego po 1990 roku. Hajnówka: Warszawska Metropolia Prawosławna.

Chrześcijańskie wychowanie. Rozważania i porady dla prawosławnej rodziny (2014). Siostry Monasteru Opieki Matki Bożej w Turkowicach (tłum., oprac., red.). Turkowice: Monaster Opieki Matki Bożej w Turkowicach.

Giddens A. (2005). Socjologia. Warszawa: Wydawnictwo Naukowe PWN.

Harbatski A. (2015). Tożsamość religijna a bezpieczeństwo konfesyjne: współczesne wyzwania (na przykładzie Republiki Białoruś). W: Pogranicze. Studia społeczne, t. XXV, Dostępny na: https://repozytorium.uwb.edu.pl/jspui/bitstream/11320/3078/1/Pogranicze_25_Harbatski.pdf (otwarty: 5.01.2019).

Informacja dotyczaca organizowania zajęć $z$ religii i etyki $w$ publicznych przedszkolach i szkołach w roku szkolnym 2016/2017. Dostępny na: https://men.gov.pl/

$20 \mathrm{~W}$ przeciwieństwie do oczywistości bycia Polakiem - katolikiem. 
ministerstwo/informacje/informacja-dotyczaca-organizowania-zajec-z-religii-i-etyki-w-publicznych-przedszkolach-i-szkolach-w-roku-szkolnym-20162017. html (otwarty: 04.02.2018).

Jaskóła P. (2010). Tożsamość wyznaniowa - problem ekumeniczny? „Roczniki Teologii Ekumenicznej", 2 (57), s. 21-33. Dostępny na: http://www.kul.pl/files/740/public/o2-Jaskola.pdf (otwarty: 10.01.2019).

Kaczorowski B. (red.). (2007). Obyczaje, języki, ludy świata. Encyklopedia PWN. Warszawa: Wydawnictwo Naukowe PWN.

Kapuściński R. (2006). Ten Inny. Kraków: Wydawnictwo Znak.

Kierdlewicz H. (red.). (2010). O naszym prawosławiu. Czykwin E. (wyb.). Białystok: Fundacja im. Księcia Konstantego Ostrogskiego.

Konferencja Wizytatorów i Doradców Metodycznych Nauczania Religii Prawosławnej z udziałem wiceministra edukacji. Dostępny na: https://men.gov.pl/ministerstwo/ informacje/konferencja-wizytatorow-i-doradcow-metodycznych-nauczania-religii-prawoslawnej-z-udzialem-wiceministra-edukacji.html\#prettyPhoto (otwarty: 05.02.2018).

Łaciak B. (1998). Świat społeczny dziecka. Warszawa: Wydawnictwo Akademickie Żak. Milerski B. (1998a). Religia a szkoła. Status edukacji religijnej w szkole w ujęciu ewangelickim. Warszawa: Chrześcijańska Akademia Teologiczna.

Milerski B. (1998b). Wspótczesne koncepcje pedagogiki religijnej. W: Milerski B. (red.). Elementy pedagogiki religijnej. Warszawa: Chrześcijańska Akademia Teologiczna.

Milerski B. (brw.). Zagrożenia i szanse polskiego protestantyzmu. Dostępny na: http://www.kosciolzbawiciela.pl/pl/blog/12 (otwarty: 10.12.2017).

Misijuk W. (2007). Naszjęzyk liturgiczny - pomoc czy utrudnienie? Białystok: Parafia Prawosławna św. Jerzego.

Modlitwy dla najmłodszych (2015). Aleksiejuk A., Aleksiejuk E. (wyb., oprac.). Ząbki: Artur Aleksiejuk.

Pezda A. (brw.). Religia w szkole to nie parafialna katecheza. Z ks. prof. Bogusławem Milerskim rozmawia Aleksandra Pezda. Dostępny na: http://wyborcza. $\mathrm{pl} / 1,87648,4822123 . h t m l$ (otwarty: 23.11.2017).

Podstawa programowa i program nauczania religii prawosławnej (2012). Pańkowski J. (oprac.). Warszawa: Warszawska Metropolia Prawosławna.

Rydz E., Bartczuk R. P., Wieradzka-Pilarczyk A. (2017), Tożsamość religijna a gotowość do wejścia w dialog międzyreligijny. „Przegląd Religioznawczy”, 2 (264). Dostępny na: https://pracownik.kul.pl/files/10427/public/artykuly/2018_rydz_ bartczuk_wieradzka_tozsamosc_a_gotowosc.pdf (otwarty: 12.01.2019).

Sanecka A. (2017). Dzielnica Wzajemnego Szacunku Czterech Wyznań i realizowane w niej programy dydaktyczne oraz ich edukacyjny potencjał. W: Humeniuk M., Paszenda I. (red.). Między ekskluzja a inkluzja w edukacji religijnej. Wrocław: Instytut Pedagogiki Uniwersytetu Wrocławskiego. 
Sitek W. (red.). (1996). Mniejszość w warunkach zagrożenia. Pamiętniki Łemków. Wrocław: Wydawnictwo Uniwersytetu Wrocławskiego

Sitek W. (1997). Wspólnota i zagrożenie. Wrocławianie wobec wielkiej powodzi. Wrocław: Wydawnictwo Uniwersytetu Wrocławskiego.

Sztompka P. (2004). Socjologia. Analiza społeczeństwa. Kraków: Wydawnictwo Znak.

Św. Łukasz. (Wojno-Jasieniecki). (brw.). Za swoich dietej daditie otwiet piered Bogom. W: Św. Łukasz. (Wojno-Jasieniecki), O siemje i wospitanii dietej. Sanecka A. (tłum.). Dostępny na: https://azbyka.ru/otechnik/Luka_Vojno-Jasenetskij/oseme-i-vospitanii-detej/\#O_2 (otwarty: 28.01.2018).

Vanca D. (brw.). Tożsamość liturgiczna i świadomość kościelna. Dostępny na: http:// orthodox.fm/tozsamosc-liturgiczna-swiadomosc-koscielna (otwarty: 20.01.2019).

Wicherkiewicz T. (2014). Ginące języki, etniczność, tożsamość i polityka. Dostępny na: http://pl.languagesindanger.eu/book-of-knowledge/endangered-languages-ethnicity-identity-and-politics (otwarty: 20.01.2019).

Wieradzka-Pilarczyk A. (2015). Tożsamość religijna młodych Polaków. Poznań: Wydawnictwo Wydziału Teologicznego UAM.

\title{
ORTHODOX DIASPORA IN WROCŁAW. PRACTICAL PROBLEMS OF SOCIALIZATION AND RELIGIOUS EDUCATION (PARENT'S PERSPECITIVE)
}

\begin{abstract}
Being a member of a minority - of any kind - brings obvious and expected impediments to functioning in different areas of life. These difficulties also concern functioning in the area of education and religious life. They are the result of objective factors, such as e.g. legal regulations, the system of teaching religion or religious traditions, as well as subjective factors, e.g. parents' lack of readiness or experiencing problems with explaining their child's "otherness" against the background of their peers brought up in majority religion. Such difficulties and problems are also experienced by members of the Orthodox Diaspora in Wrocław. These difficulties are known and felt especially by parents, but also by children after reaching certain age and certain awareness. The article presents practical problems with religious socialization and teaching religion seen through the eyes of an Orthodox parent. However, it also indicates some opportunities resulting from emerging difficulties.
\end{abstract}

Keywords: religious socialization; teaching religion in school; minority religion; Orthodox diaspora.

Anna Sanecka - socjolog, doktor teologii. Od 2018 roku doktorantka Wydziału Studiów Stosowanych Dolnośląskiej Szkoły Wyższej we Wrocławiu. Zainteresowania naukowe: gerontologia społeczna, pedagogika kultury i religii, teologia medycyny. Adres korespondencyjny: Wydział Nauk Pedagogicznych DSW, ul. Strzegomska 55, 53-611 Wrocław. Adres e-mailowy: anna.sanecka@gmail.com. 